\title{
Control of Artificial Light for Plants
}

\section{Simulation and Monitoring of Spectral Composition}

\author{
Tsuyoshi Matsui, Hiromi Eguchi, and Yasuhiko Soejima \\ Biotron Institute, Kyushu University, Fukuoka, Japan
}

(Received April 28, 1976)

\begin{abstract}
A device of simulation and display was developed for monitoring the controlled spectral composition of artificial light for plants. The simulation was performed in the following manner:

The spectral intensity at rated capacity is denoted by the function of wavelength, $\lambda$. Individual function, $f_{i}(\lambda), i=1,2, \cdots 6$, of six kinds of the lamps is coded in digital form on ROM in the function generator and is used to generate voltage value, $V_{f_{i}(\lambda)}$. A dimming parameter $k_{i}$ is converted into voltage value, $V_{k_{i}}$ in the potentiometer. The $V_{f_{i}(\lambda)}$ is multiplied by the $V_{k_{i}}$ to produce voltage value corresponding to an optional spectral intensity of each kind of the lamps. These multiplied values of $V_{k_{1}} V_{f_{1}(\lambda)}, V_{k_{2}} V_{f_{2}(\lambda)}, \cdots$ and $V_{k_{6}} V_{f_{6}(\lambda)}$ are summed up in the summing amplifier to manipulate $F(\lambda)$ which is displayed on the CRT as the spectral composition of combined light. The signals from potentiometers are also used as actuating signals in light control system.

Thus, the change of spectral composition with the variation of each parameter was examined immediately on the CRT, and at the same time, the spectral composition was controlled. Experimental results demonstrate that the simulation method employed is satisfactory for the evaluation of the spectral composition, and the developed system makes it possible to monitor the spectral composition in artificial light control.
\end{abstract}

Adequate control of intensity and spectral composition of light is needed for studies on plant response to the light. ${ }^{1-4}$ ) In the previous papers, we reported on an automatic control system of intensity and spectral composition of artificial light for plants, where the control of spectral composition of combined light was made possible by varying individual light outputs of six kinds of the lamps..$^{5,6}$ )

Further need is to develop a device for immediate estimation of the spectral composition controlled at various desired values. Present paper deals with instrumentation for monitoring the spectral composition in artificial light control.

\section{SYSTEM AND PERFORMANCE}

Figure 1 shows the control system of spectral composition, which was reported in the previous papers. The spectral composition is represented as a function of wavelength, $\lambda$. In this system, the spectral composition of combined light, $F(\lambda)$ was given by

$$
F(\lambda)=k_{1} f_{1}(\lambda)+k_{2} f_{2}(\lambda)+k_{3} f_{3}(\lambda)+k_{4} f_{4}(\lambda)+k_{5} f_{5}(\lambda)+k_{6} f_{6}(\lambda),
$$

where $f_{i}(\lambda), i=1,2, \cdots 6$, is the basic spectrum, and $k_{i}$ is the dimming parameter 


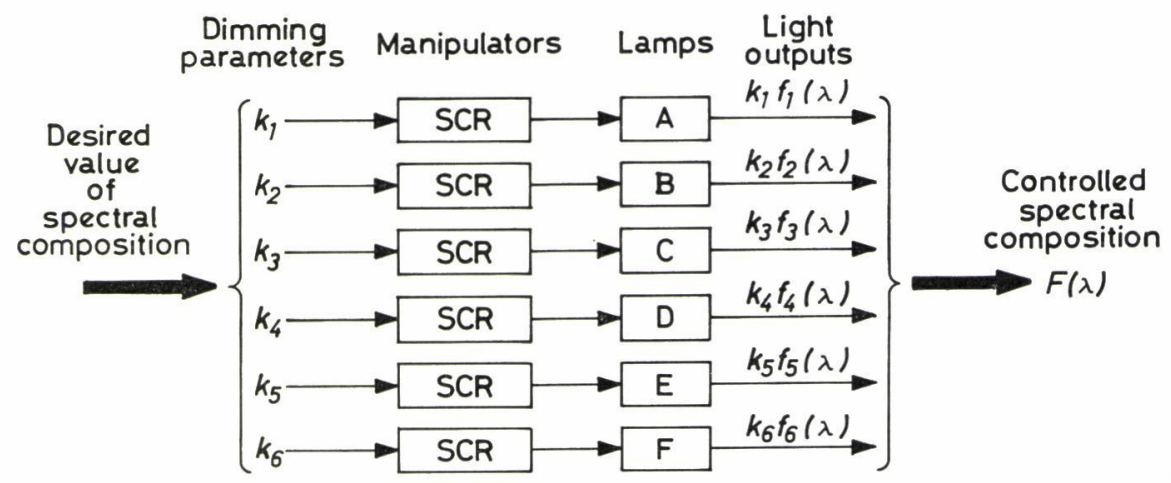

Fig. 1 Block diagram of light control system.

of light output of respective lamps A, B, . . and F. In the present experiment, the basic spectrum was defined as the spectral intensity at rated capacity, measured at a distance of $100 \mathrm{~cm}$ from the lamps by the spectroradiometer. ${ }^{6)}$ The spectral intensity of each kind of the lamps depends on emission characteristics of phosphor or filament temperature and can be changed in proportion to the dimming parameter which is corresponding to the effective current through the lamps. On the basis of this fact, a simulator of the spectral composition was designed. A photograph of the general view of the simulator is shown in Fig. 2. Figure 3 shows the schematic diagram of the system.

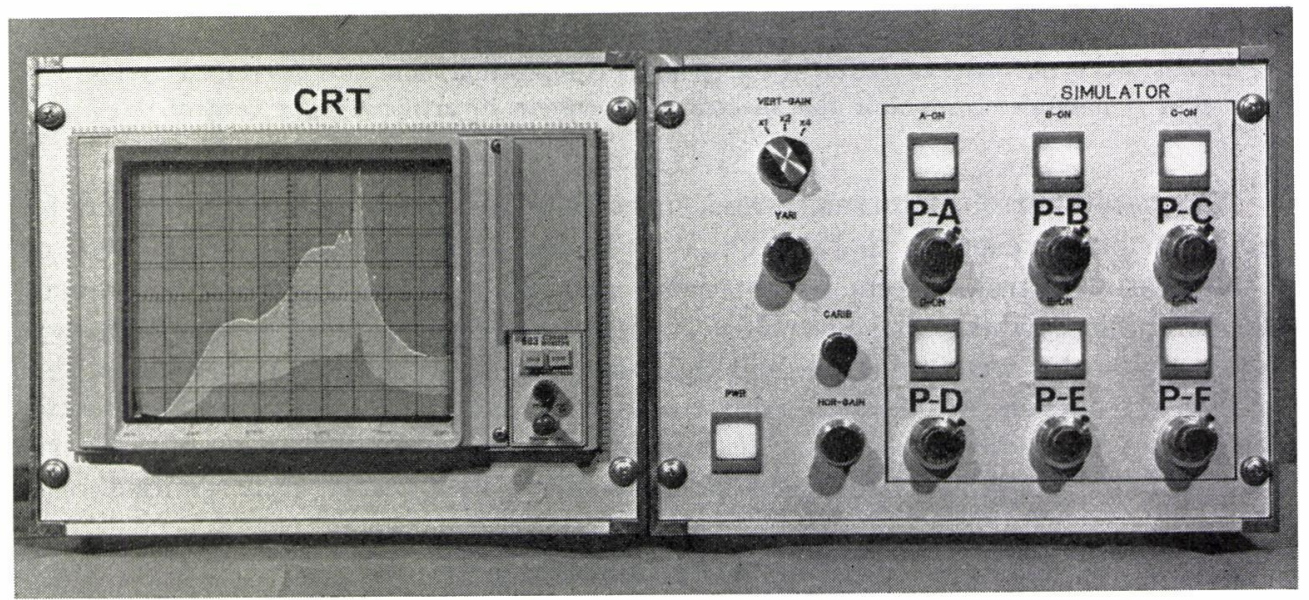

Fig. 2 General view of simulator.

CRT, storage cathode-ray tube display; P-A, B, $\cdots$ and F, potentiometers for respective function generators.

The simulator is provided with function generators, potentiometers, multipliers, a summing amplifier, a storage CRT display (a storage cathode-ray tube display, 603 Monitor, Tektronix) and outputs. The function generator consists of 


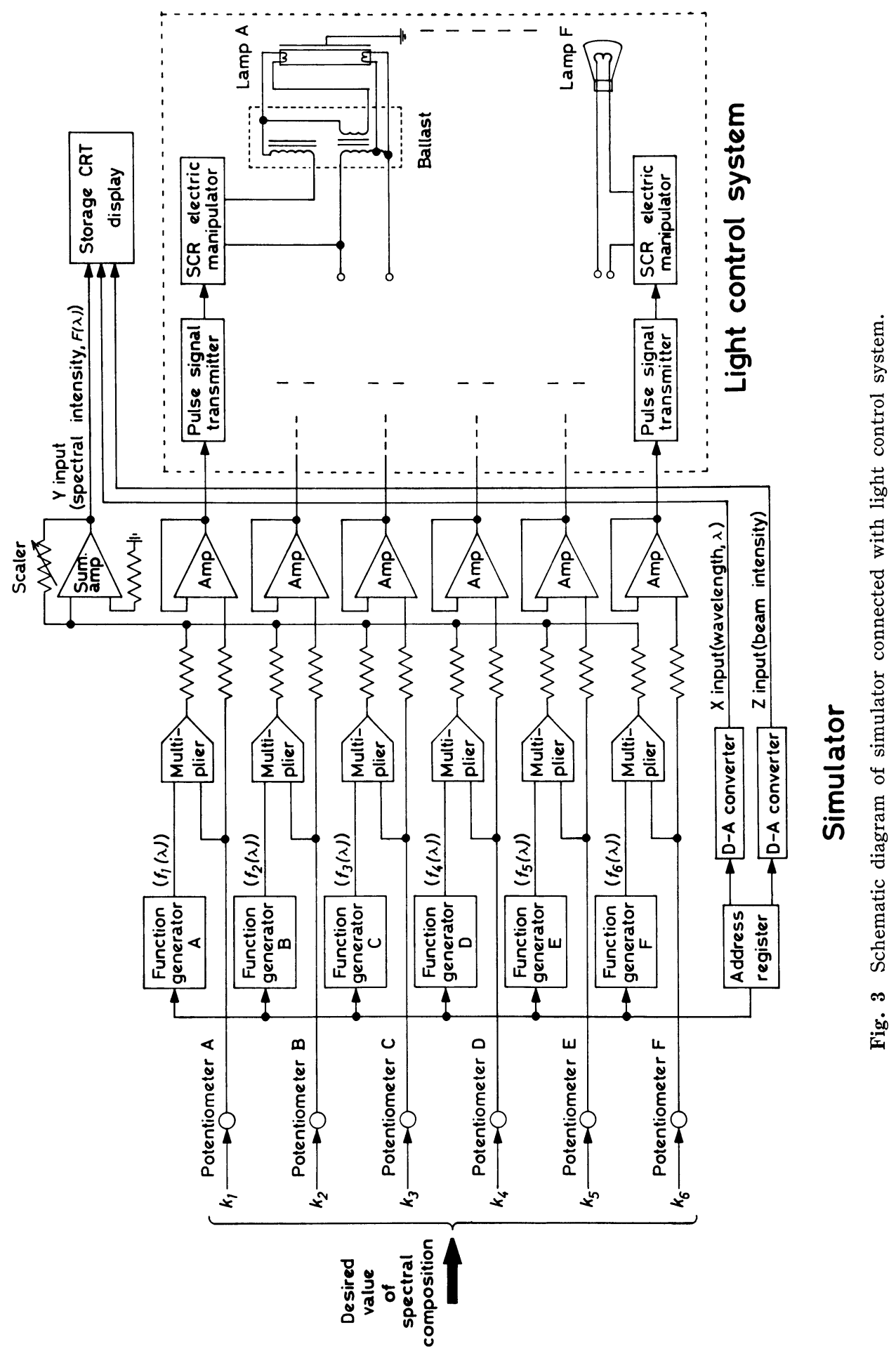


a memory unit and a D-A converter, which is applied for the generation of a function, $f_{i}(\lambda)$. A ROM (read only memory) with 256 words ( 8 bits/word) is used as the memory element. ${ }^{7)}$ Each basic spectrum is coded in digital form at a sampling interval of $5 \mathrm{~nm}$. The coded function is read back by the address register through the $\mathrm{D}-\mathrm{A}$ converter. The potentiometer is used for setting parameter, $k_{i}$ which is converted into voltage value, $V_{k_{i}}$. On the other hand, the voltage value, $V_{f_{i}(\lambda)}$ of each output from the function generators is multiplied by $V_{k_{i}}$, to produce a voltage value corresponding to $k_{i} f_{i}(\lambda)$ through the multiplier as shown in Fig. 4.

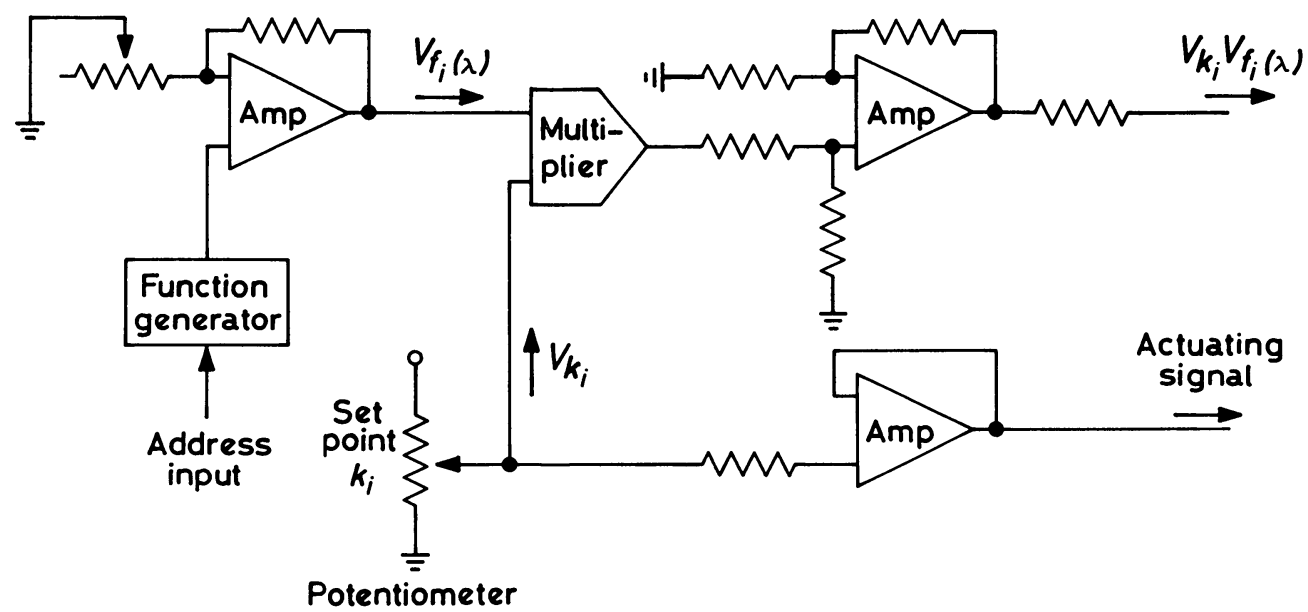

Fig. 4 Circuit for calculation of spectral intensity, $k_{i} f_{i}(\lambda)$.

These voltage signals of $V_{k_{1}} V_{f_{1}(\lambda)}, V_{k_{2}} V_{f_{2}(\lambda)}, \cdots$ and $V_{k_{6}} V_{f_{6}(\lambda)}$ are summed up in the summing amplifier to manipulate $F(\lambda)$ which is displayed on the CRT as the spectral composition of combined light. The set point of $k_{i}$ in potentiometer is also converted into the voltage values from $10 \mathrm{~V}$ to $20 \mathrm{~V}$ to be used as actuating signal in light control system.

Thus, the change of spectral composition $F(\lambda)$ with the variation of each parameter was examined immediately on the CRT, and at the same time, spectral composition was controlled by using the signals generated on the basis of each parameter, $k_{i}$. Figures 5 (a) and (b) show the spectral compositions of light from each kind of the lamps and combined lamps at rated capacity. The upper figure (a) shows the simulated values displayed on the CRT and the lower one (b) shows the controlled spectral irradiance measured at a distance of $100 \mathrm{~cm}$ from the lamps by the spectroradiometer. In these figures, horizontal and vertical scales were adjusted to the same value. The intensities of mercury line spectra were omitted in this simulation. The simulated value agreed with measured one within a small error of several per cent of the full scale. Figure 6 shows the spectral compositions of the light from blue fluorescent lamps at different settings of parameter, $k_{1}$. Simulated values illustrated the similar pattern of controlled variables measured by above condition. However, the differences of the output in higher and lower intensities between simulated and measured values became 
a

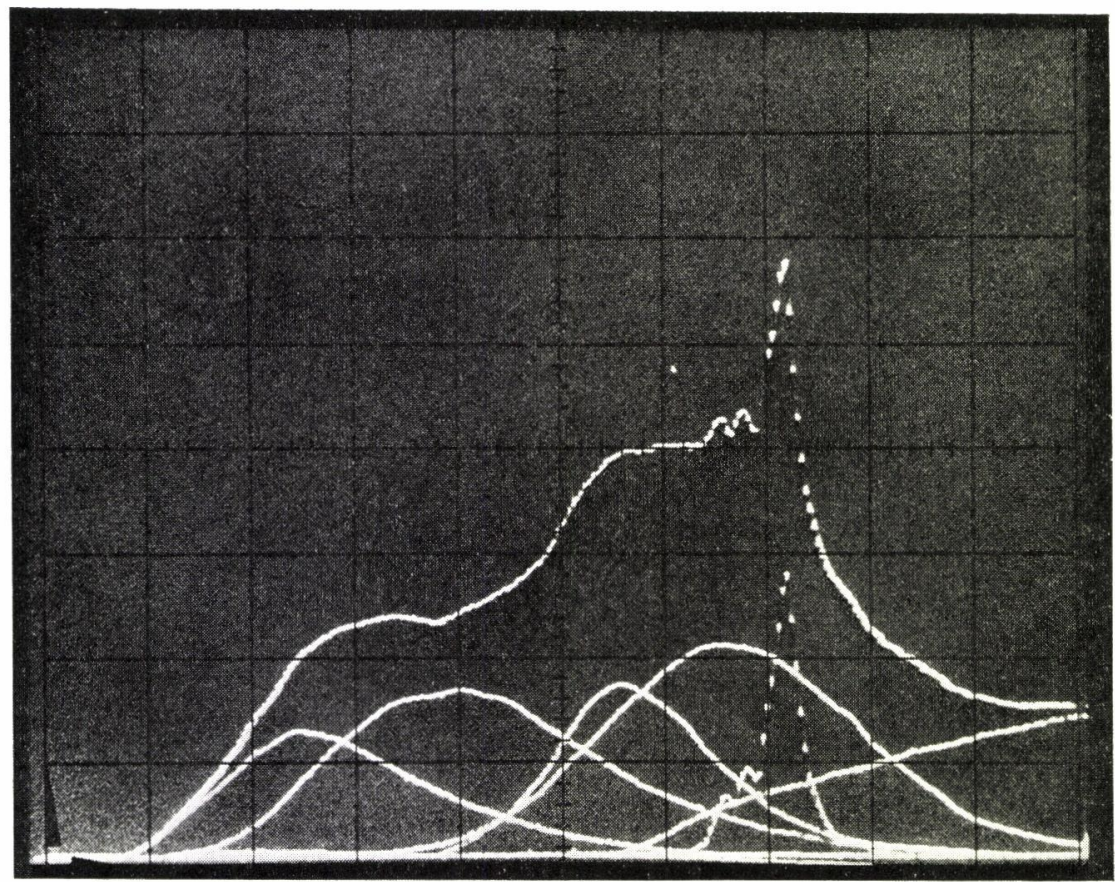

b

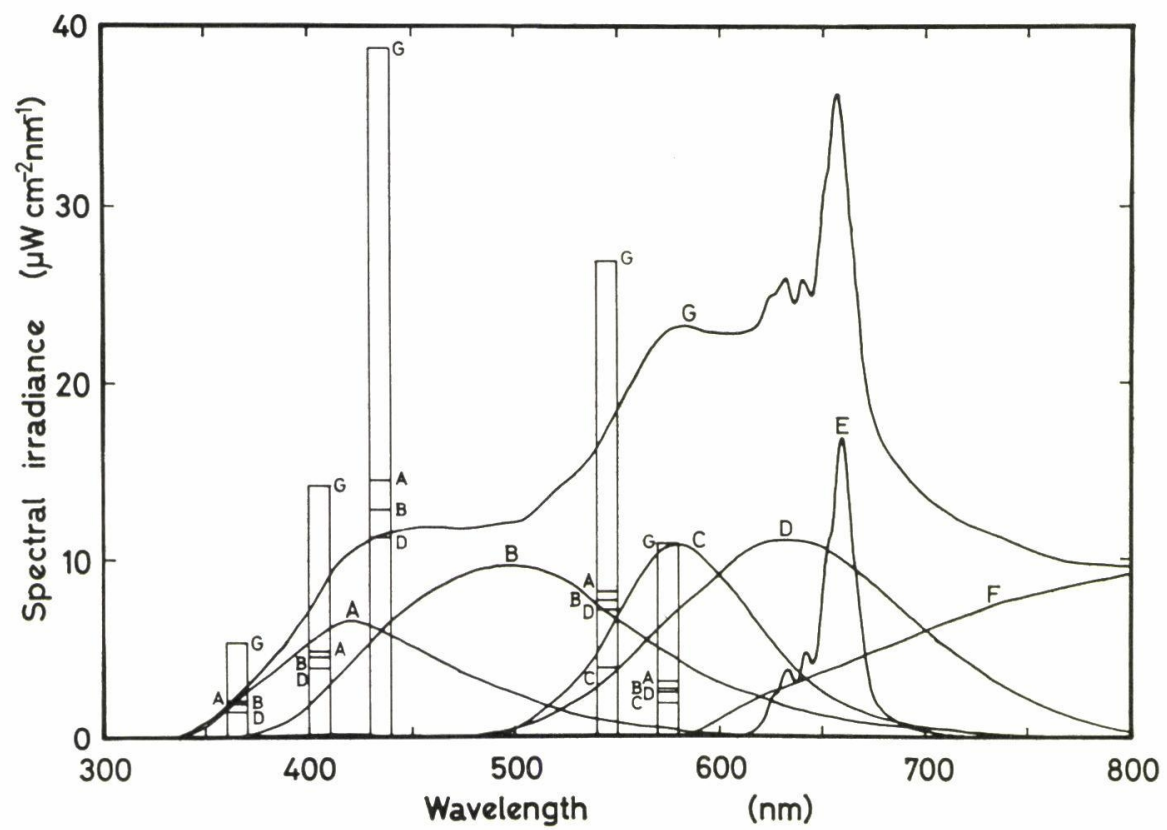

Fig. 5 Spectral composition of light from each kind of the lamps and combined lamps at rated capacity.

A, blue; B, blue-white; C, yellow; D, pink; E, red fluorescent lamps; F, red beam lamps; G, combined lamps.

a: Simulated curve. b: Measured curve. 
$\mathbf{a}$
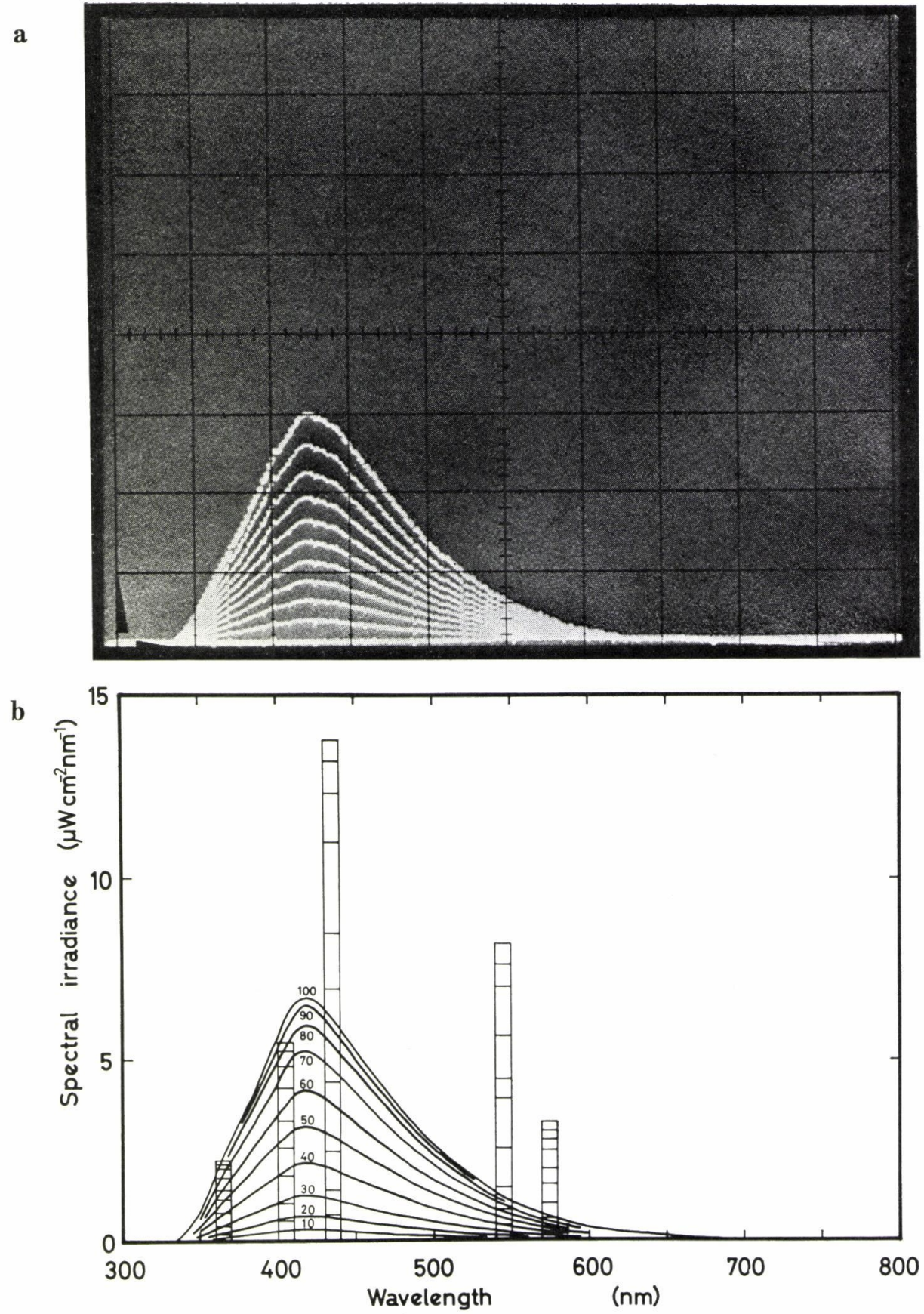

Fig. 6 Spectral compositions of the light from blue fluorescent lamps at different settings of parameter $k_{1}$ : where the numbers of curves show the set points of potentiometers (relative value).

a: Simulated curve. b: Measured curve. 
larger to some extent. The main reason of the error was due to the facts that there is no linearity between light output and set point of dimming parameter, and further, there are some deviations arround the response curve as shown in Fig. 7. Figure 8 shows an example of the simulated and measured values,

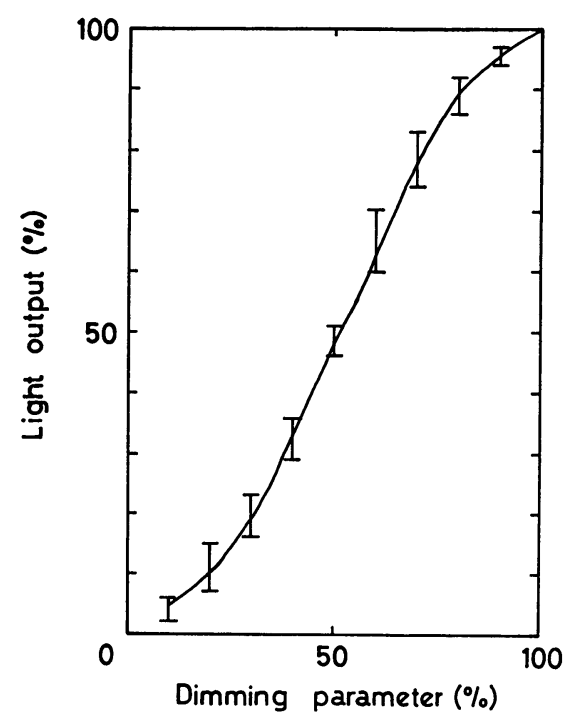

Fig. 7 Response curve in light output control.

where the spectral composition was controlled by setting the parameters to obtain flat spectrum within the wavelength range between $450 \mathrm{~nm}$ and $650 \mathrm{~nm}$. Figure 9 shows the dynamic range of long wavelength region, in which light output of D lamps (pink fluorescent lamps) was changed from $0 \%$ to $100 \%$. The dynamic range was displayed on the CRT operating stored mode.

These results demonstrate that the simulation method employed here, is satisfactory for the evaluation of the spectral composition, and this developed system makes it possible to monitor the spectral composition in artificial light control.

\section{CONCLUSION}

Owing to the system response of this device, the simulated value was not equal to the measured one. It is known that the light output of lamp is, in general, not constant and is subjected to a deviation of about $10 \%$ of rated capacity due to the fact that the light output is affected by several factors, such as line voltage, ballast quality, ambient temperature, number of starts, starting frequency, hours of burning and the others. ${ }^{8)}$ From this view point, it can be concluded that the accuracy of simulation is sufficient enough for the purpose of spectral composition control. Thus, monitoring and display of spectral composition were made possible by the present device in conjunction with the automatic control system of artificial light radiation for plants. 
a
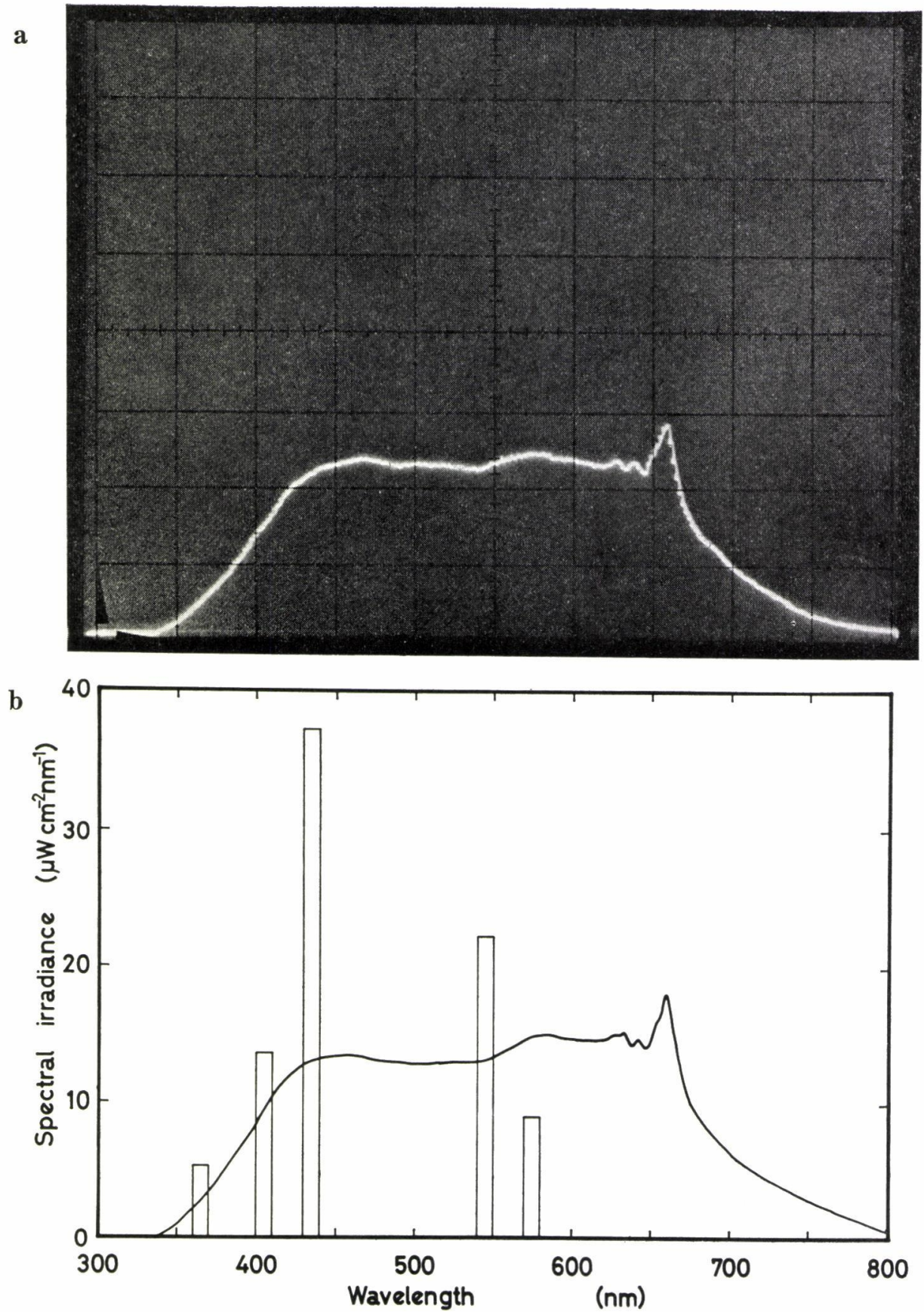

Fig. 8 An example of the simulated and measured values: where the spectral composition was controlled by setting the parameters to obtain flat spectrum within the wavelength range from $450 \mathrm{~nm}$ to $650 \mathrm{~nm}$.

a: Simulated curve. b: Measured curve. 


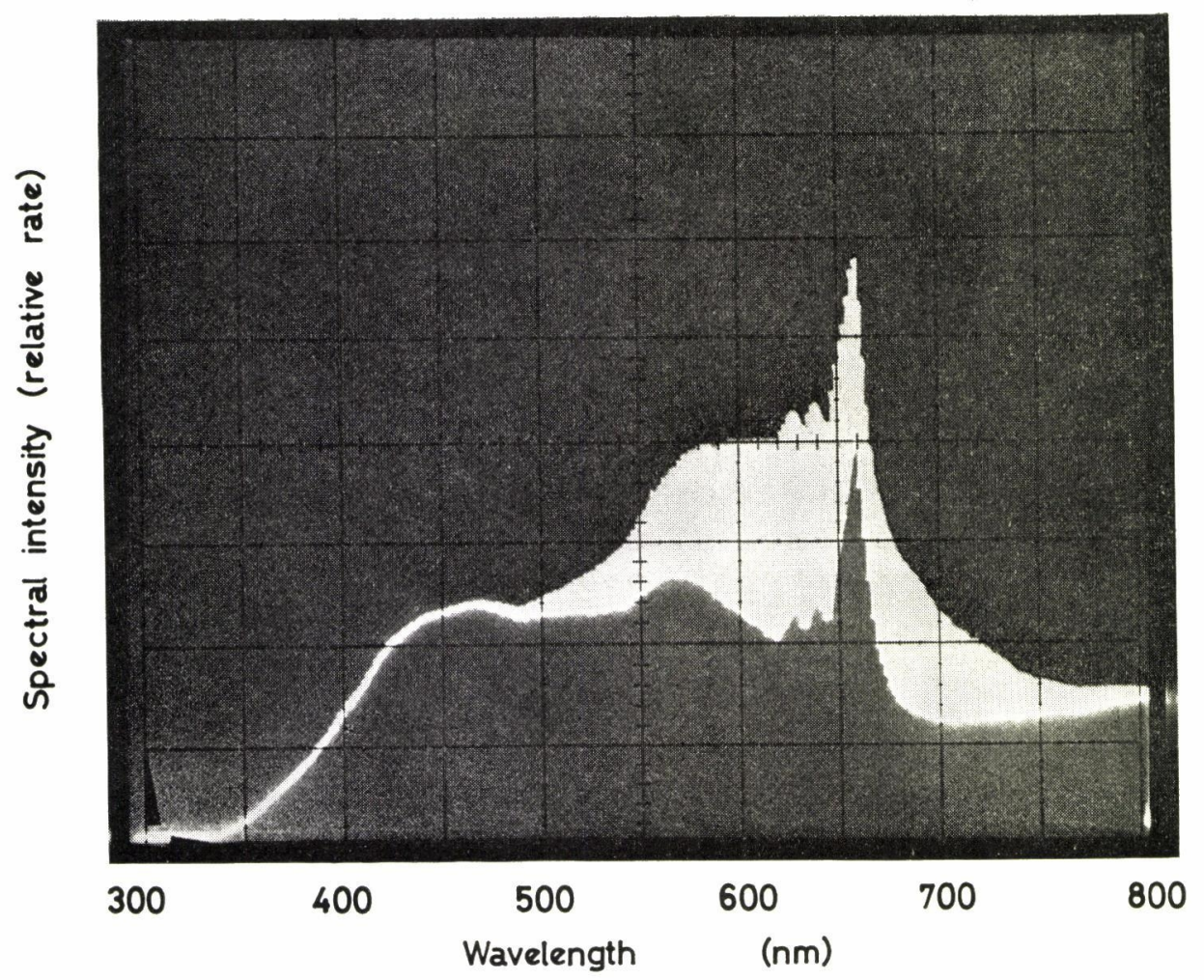

Fig. 9 Dynamic range of long wavelength region displayed on the CRT operating stored mode: where the light output of D lamps (pink fluorescent lamps) was changed from $0 \%$ to $100 \%$ of rated capacity.

\section{REFERENCES}

1) Kalbfleisch, W. 1963. Artificial light for plant growth. In "Proceedings of a Symposium on Engineering Aspects of Environment Control for Plant Growth" (CSIRO Symposium, Sept., 1962) 159-174, Victoria, Australia.

2) Downs, R. J., and W. A. BAILEY. 1967. Control of illumination for plant growth. In "Methods in Developmental Biology" (Eds. by Wilt, F. H. and Wessels, N. K.) 635-644, Thomas Y. Crowell Co., New York.

3) BICKFord, E. D., and S. DunN. 1972. Lighting for Plant Growth. Kent State University Press, USA.

4) ISHIgURI, Y., Y. ODA, and K. INADA. 1975. Spectral dependences of flowering in Lemna perpusilla and L. gibba. Plant Cell Physiol. 16: 521-523.

5) Matsui, T., Y. Soejima, and H. Eguchi. 1974. Control of artificial light for plants. I. Measurement and control of light. Environ. Control in Biol. 12: 53-68.

6) Matsui, T., H. Eguchi, Y. Soejima, and M. Hamakoga. 1975. Control of artificial light for plants. II. Automatic control of light intensity and spectral composition. Environ. Control in Biol. 13: 109-116.

7) LueCke, G., J. P. Mize, and W. N. CARR. 1973. Fixed program and sequentially addressed memory applications. In "Semiconductor Memory Design and Application" (Ed. by R. E. Sawyer) 187-208, McGraw-Hill Kogakusha, Ltd., Tokyo. 
8) IES Lighting Handbook. 1972. Ed. by J. E. Kaufman, 5th Ed., Illum. Eng. Soc., New York.

\title{
〈和文抄録〉
}

\author{
植物に対する人エ光照射の制御 \\ III. 光スペクトル組成のシミュレーションとモニタリング \\ 松井健・江口弘美・副島泰彦 \\ 九州大学生物環境調節センター
}

前報では植物に対する人工光照射の自動制御を目的とした装置の開発とその特性解析について報告し た. この装置ではスペクトル組成の異なる 6 種のランプを光源として用い, 各ランプの光出力を操作す ることによりスペクトル組成の制御を可能とした．本報では, 制御スペクトル組成のモニタリングのた めに, シミュレータと表示装置を試作しその特性を解析した。

シミュレーションには次の方式をとった。前報の光制御装置で用いた 6 種のランプの発光スペクトル 強度はそれぞれ波長の関数として表わされる。 また合成されたスペクトル強度は各ランプのスペクトル 強度の和として示される．そこで各ランプの定格点燈におけるスペクトル強度を $5 \mathrm{~nm}$ のサンプリング 間隔でディジタル化し，記憶素子 ROM（8 ビット・256 ワード）にコーディングした。この記憶され た関数を A-D 変換器を通して関数発生器より出力した. 次にポテンシオメータで設定した各ランプの 光出力の設定值に対応したパラメータと関数発生器の出力值とをバッフォアンプを用いて乗じた. この 乗算值をサミングフンプにより波長ごとに加算し合成された光のスペクトル組成としてストーレッジ CRT 上に表示した. それと同時にポテンシオメータの設定値を光制御装置における調光信号として用 いた.

この方式により各ランプの調光パラメータに対応したスペクトル組成の変化をモニタリングしながら 光スペクトル組成を制御することが可能となった。シミュレート值と計測值は良く近似しており，スペ クトル組成のモニタリング装置としては十分な性能で有効であることがわかった。 